\title{
PEKERJA SOSIAL DAN PENYELESAIAN KONFLIK DI INDONESIA
}

\author{
Oleh: \\ Usep Rochmat, Nandang Mulyana, \& Maulana Irfan \\ Email: \\ (rochmatusep553@gmail.com; mulyanandang@gmail.com; sangirfan@gmail.com)
}

\begin{abstract}
ABSTRAK
Konflik merupakan tindakan kejahatan yan dilakukan oleh manusia dalam hal prilaku kehidupannya. Konflik pun tidak bisa dihilangkan dari diri manusia itu sendiri, karena konflik merupakan suatu sikap yang dimiliki manusia atas dasar perbedaan, baik untuk diri sendiri maupun kelompok atau organisasi. Yang perlu di lakukan adalah bagai mana caranya melakukan proses penyelesaian konflik dengan baik, dan sesuai dengan hukum yang sudah ditentukan. Penegakan hukum yang sesuai, serta menjalankannya dengan baik akan mengurangi tindakan terjadinya konflik kembali. Dalam kaitannya dengan konflik, tentunya yang harus menjadi perhatian adalah orang-orang yang harus terlibat dalam resolusi konflik. Seperti dalam resolusi konflik atau penyelesaian konflik melalui jalur Non-Litigas. Dalam proses resolusi konflik jalur Non-Litigasi ini memerlukan orang yang handal dalam memerankan diplomasi ini Non-Litigasi ini. Seperti Negosiator, Mediator, dan itu dapat dilakukan oleh seorang pekerja sosial. Karena seorang pekerja sosial sudah dibekali dengan berbagai ilmu elekti lainnya, dalam proses kemanusian, dan akan sangat tepat jika pekerja sosial terlibat di dalam resolusi konflik-konflik di Indonesia.
\end{abstract}

Kata kunci: Peran pekerja social dalam Resolusi konflik

\section{PENDAHULUAN}

Konfik merupakan suatu tindakan yang dilakukan oleh manusia terhadap manusia yang lainnya. Baik itu secara individu maupun kelompok, konflik merupakan tindakan kejahatan karena mencederai nilai-nilai prikemanusian, dan selalu memakan korban yang tidak sedikit, naun sepanjang manuisia masih hidup dan berada di muka bumi maka demian pula konflik akan selalu ada. Sebagai mausia adalah meminimalisir kejadian konflik di tengah-tengah ke hidupan kita, agar tecipta suatu rasa aman kebersamaan, sepanjang sejarah manusia di muka bumi ini konflik sudah sering kali terjadi, bahkan sebelum perang dunia I dan perang dunia ke II pun yang di sebut sebagai konflik yang sangat besar, konflik sudah terjadi jauh sebelum itu terjadi, sudah sering melanda umat manusia di muka bumi ini. Karena pada dasarnya konflik diciptakan oleh manusia itu sendiri yang bersandar pada kepentingan mereka masing-masing. Karena manusia hidup di bumi membawa kepentingannya masing-masing, sehingga pada dasarnya konflik akan selalu terjadi pada sendi-sendi kehidupan manusia.

Sejarah mencatat konflik yang terjadi di tengah-tengah kehidupan manusia ternyata itu di ciptakan oleh manusia itu sendiri karena kepentingan yang mereka pertahankan, dan mereka anggap benar, baik untuk mereka sendiri secara individu maupun secara kelompok atau organisasi. Sehingga 
pada dasarnya konflik tidak akan hilang dari kehidupan manusia, namun hanya dapa dit cegah agar tidak terus terjadi dan meninggalkan korban terhadap manusia lainnya. Bencana konflik lebih menekankan dan berakibat pada bencana sosial yang selalu berkepanjangan, bencana konflik bisa juga di sebut bencana sosial karena akan berdampak pada tatanan dan nilai-nilai sosial yang berada pada masyarakat itu sendiri, dan lebih merusak dari pada bencana yang di timbulkan oleh bencana Alam. Bencana sosial yang ditimbulkan karena konflik selalu berujung pada nilai-nilai sosial dan akan menggerus atau memaksa nilai-nilai sosial menjadi berubah karena konflik terjadi pada masyarakat. Seperti yang sudah di singgung sebelumnya bahwa yang namanya konflik akan selalu terjadi pada tatanan kehidupan manusia, selama manusia itu berada. Karena konflik menjadi ciri khas manusia untuk mempertahankan dirinya dan kepentinganya masing-masing. Meskipun tidak sama dengan yang terjadi pada makhluk hidup lainnya, seperti hewan. Namu justru konflik manusia jauh lebih patal dari pada konflik hewan, karena ketika manusia itu konflik dengan manusia yang lainnya, yang digunakan oleh manusia tidak hanya nafsu namun akal dan fikiran, sehingga manusia mempunyai cara yang lebih banyak untuk mengalahkan lawannya dalam konflik tersebut, dan korban pun bisa menjadi lebih banyak. Ketika dua orang manusia terlibat konflik maka yang akan terjadi ketika konflik itu muncul yang kedua kalinya akan menjadi dua kubu yang akan berkonflik, sehingga akibat dari konflik tersebut akan semakin luas dan semakin banyak juga menimbulkan korbannya.

Konflik identikya akan menimbulkan luka yang amat mendalam bagi mereka yang terkena konflik, apa lagi bagi mereka yang terlibat langsung dalam konfliknya. Bahkan mereka akan sangat susah untuk melupakan konflik tersebut, sehingga berujung pada dendam dan akan menimbulkan konflik kembali. Sejauh ini konflik pada manusia yang dilandasi karena kepentingan, baik kepentingan jabatan, atau kekuasan, baik dalam kekuasan bisnis, mau pun perkara kekuasaan di pemerintahan, bahkan berkaitan dengan kepentingan Agama pun tidak kalah menarik dari kepentingan lainnya. Malah justru konflik yang terjadi akibat agama atau yang di sebut dengan konflik horizontal, lebih banyak menimbulkan kerusakan yang berlipat dari pada konflik yang dusebabkan oleh konflik lainnya, seperti konflik, karena kekuasan bisnis, budaya, dan lainnya.

Konflik yang di sebabkan oleh kesalah pahaman karena agama yang satu dengan agama yang lainnya, selalu memberikan misteri yang sangat mengerikan, kejadiannya di negara kita Indonesia tepatnya di poso, konflik poso merupakan konflik yang di sebabkan karena kesalah pahaman antar umat beragama, sehingga menimbulkan korban dan kerugian yang sangat luar biasa besarnya, bahkan bisa mengganggu kesetabilan dan keutuhan negara tersebut, karena pada tahap penyelesaian konflik tersebuat akan mendapatkan interfensi dari Negara lain, yang bisa saja menekankan tidak condong kesalah satu pihak saja. Sehingg kasus konflik sunggung sangat berat dalam proses penyelesaiannya. Namun sebagai manusia yang sering menciptakan konflik maka harus mampu untuk menyelesaikan konflik tersebut, baik sekala individu, kelompok atau golongan dan organisasi.

\section{PEMBAHASAN}

Keanekaragaman suku, agama, ras, dan budaya Indonesia dengan jumlah penduduk lebih dari 230 juta jiwa, pada satu sisi merupakan suatu kekayaan bangsa yang secara langsung ataupun tidak langsung dapat memberikan kontribusi positif bagi upaya menciptakan kesejahteraan masyarakat. Namun pada sisi lain, kondisi tersebut dapat membawa dampak buruk bagi kehidupan nasional apabila terdapat ketimpangan pembangunan, ketidakadilan dan kesenjangan sosial dan ekonomi, serta ketidakterkendalian dinamika kehidupan politik.( sumber UU No 7 Tahun 2012). Sehingga ini berdampak pada kesetabilan sosial, dan mempengaruhi keutuhan Negara kesatuan Republik Indonesia, seperti terjadinya konflik dan kekerasan yang terjadi di negara Indonesia.

Seperti yang sering kita saksikan di berbagai media, baik mdia Elektronik mau pun media cetik, benturan fisik yang sering kita sebut dengan konflik akhir-akhir ini sering terjadi di berbagai daerah di Indonesia. Sehingga perlu adanya suatu kebijakan dan tindakan yang mendorong dalam penyelesaian konflik atau resolusi konflik. Perlu di akui tindakan aparat penegak hukum memang 
sudah menunjukan adanya kemauan untuk mengendalikan konflik-konflik yang terjadi di setiap daerah-daerah yang ada di Indonesia ini. Tindakan tegas oleh aparat penegak hukum, seperti kepolisian memang patut di apresia oleh bangsa Indonesia, karena apa pun yang di lakukan oleh kepolisian memang sangat memberikan harapan bagi bangsa Indonesia kalau lah mereka mempunyai tanggung jawab yang tinggi untuk menyelesaikan dan mengendalikan konflik-konflik yang terjadi di berbagai daerah di Indonesia. Namun ada satu yang kurang, diantaranya ketika memberikan soslusi atau pada saat ingin mendamaikan atau kembali merujukan kedua belah pihak yang konflik sering tidak tepat sasarannya.

Ketika melakukan negosiasi atau proses mediasi sering terjadi keselahan, antara yang berkonflik dan yang tidak berkonflik, yang berkonfliknya siapa, dan yang di suruh negosiasi dan mediasinya siapa, sehingga tidak ada kesepakatan diantara kedua belah pihak yang berkonflik. Padahal seharusnya yang konfllik lah yang harus disuruh atau di mediasi dalam resolusi kinflik itu sendiri. Juga sering terjadinya Negosiator dan mediator, mereka yang kurang menguasai proses tersebut sehingga kesepakatan yang di lakukan menjadi Win-los. Padahal yang di harapkan dalam proses tersebut adalah Win-Win solution, sehingga ada kesepakatan yang pasti antara kedua belah pihak yang berkonflik. Disini lah diperlukan orang yang secara menyeluruh mempuhnyai kemampuan dalam melakukan kedua hal tersebut, menjadi Negosiator dan Mediator yang baik dalam proses Resolusi konflik di Indonesia.

Pekerja sosial adalah mereka yang tepat untuk terlibat dalam proses Resolusi konflik, seperti menjadi Negosiator atau pun Mediator, karena untuk seorang Negosiator dan Mediator, tidak hanya sekedar mengetahui atau memahami ilmu tersebut, namun terlebih harus mengetahui dan memahami keadaan manusia atau orang yang terlibat konflik, bagai mana memberikan pandangan, dan arahan kepada kedua belah pihak yang berkonflik, dan itu yang menguasai adalah pekerja sosaial, karena mereka adalah diajari prihal berhadapan dengan manusia. Karena pada dasarnya konflik merupakan tindakan kekerasan yang sangat mendalam, seperti pengertian berikut:

Pengertian kekerasan dalam arti luas diajukan oleh Johan Galtung yang mendefinsikan kekerasan sebagai "any avoidable Impediment to self realization" (sesuatu yang menyebabkan orang tidak bisa mengaktualisasikan diri secara wajar). Penghalang itu menurut Galtung sebenarnya dapat dihindarkan, dan oleh karenanya kekerasan sebenarnya bisa dihindarkan kalau penghalang itu disingkrikan.

Pekerjaan sosial (social work) yang dimaksud dalam tulisan ini bukanlah kegiatan-kegiatan sukarela atau pekerjaan-pekerjaan amal begitu saja, melainkan sebuah profesi pertolongan kemanusiaan yang fokus utamanya untuk membantu keberfungsian sosial (social functioning) individu, keluarga, dan masyarakat dalam melaksanakan peran-peran sosialnya (Siporin, 1975; Morales dan Sheafor, 1989; Zastrow, 1982; 1989; Suharto, 1997). Dianalogikan dengan profesi kedokteran yang bergerak dalam bidang kesehatan atau profesi guru yang bertugas dalam domain pendidikan, maka tugas dan peran pekerjaan sosial lebih dominan dalam arena kesejahteraan sosial (social welfare). Dalam menjalankan tugas-tugas profesionalnya, para pekerja sosial dilengkapi dengan seperangkat ilmu (body of knowledge), keterampilan (body of skills) dan nilai (body of value) yang secara eklektik dibangun dari ilmu politik, psikologi, sosiologi, antropologi dan filsafat sosial. Kompetensi pekerja sosial profesional umumnya diperoleh melalui pendidikan formal (S1, S2 dan S3). Jadi sangat jelas kalau pekerja sosial bukan lah seorang pekerja yang tampa tujuan, atau hanya pekerja sukarela, melaikan sebuah profesi dan domainnya adalah untuk memberikan kesejahteraan seperti yang sudah di jelaskan di atas. Terkait dengan resolusi konflik pekerja sosial memiliki kemapuan dalam membangun dinamika hubungan antar manusia sesuai dengan kaidah ke ilmuan pekerja sosial.

Mengacu pada Parsons, Jorgensen dan Hernandez (1994), ada beberapa peran pekerjaan sosial dalam penanganan konflik. Tiga peran di bawah ini - mediator, fasilitator dan broker - sangat relevan dalam proses penanganan konflik dan dapat dijadikan model bagi para pendamai, khususnya bagi 
mereka yang terlibat dalam kegiatan-kegiatan pembimbingan sosial yang bertugas di lapangan. Peran mediator dilakukan pada tahap berlangsungnya konflik. Sedangkan peran fasilitator dan broker umumnya dilakukan pada fase "paska konflik" dimana "pertempuran" dan "benturan-benturan fisik" sudah menurun. Dua peran ini sering pula diterapkan pada tahap pra-konflik atau pencegahan konflik. 


\section{Mediator}

Pekerja sosial sering melakukan peran mediator dalam berbagai kegiatan pertolongannya. Peran ini sangat penting dalam penanganan konflik, terutama pada fase berlangsungnya konflik. Peran mediator dilakukan pada saat terdapat perbedaan yang mencolok dan mengarah pada clash fisik antara berbagai pihak. Dalam konteks ini, pekerja sosial dapat memerankan sebagai "fungsi kekuatan ketiga" untuk menjembatani antara anggota kelompok dan sistem lingkungan yang menghambatnya. Ini lah yang dimiliki oleh pekerja sosial dalam penangan konflik yang terjadi di Indonesia, karena pada dasarnya konflik merupakan suatu kodratan manusia yang tak bisa di hilangkan dalam kehidupan manusia. Konflik hanya dapat di minimalisir atau di kendalikan da dicegah supaya tidak terjadi secara luas dan sering meletus,bagai mana pun itu konflik hanya dapat di di sikapi dengan resolusi dan penyelesaian yang berkeadalin, dan orang-orang yang turut dalam penyelesaian konflik haruslah mereka yang benar-benar mempunyai kemampuan dalam mewujudkan kedamaian dalam konflik tersebut, dan itu pekerja sosial memiliki kemampuan untuk penanganan konflik di Indonesia ini. Dalam prosesnya pekerja sosial, sebagai Mediator atau Negosiator, mempunyai strategi, seperti yang di kemukakan oleh, Compton dan Galaway (1989: 511) memberikan beberapa teknik dan keterampilan yang dapat digunakan dalam melakukan peran mediator: sebagai berikut.

- Mencari persamaan nilai dari pihak-pihak yang terlibat konflik.

- Membantu setiap pihak agar mengakui legitimasi kepentingan pihak lain.

- Membantu pihak-pihak yang bertikai dalam mengidentifikasi kepentingan bersama.

- Hindari situasi yang mengarah pada munculnya kondisi menang dan kalah.

- Berupaya untuk melokalisir konflik kedalam isu, waktu dan tempat yang spesifik.

- Membagi konflik kedalam beberapa isu.

- Membantu pihak-pihak yang bertikai untuk mengakui bahwa mereka lebih memiliki manfaat jika melanjutkan sebuah hubungan ketimbang terlibat terus dalam konflik.

- Memfasilitasi komunikasi dengan cara mendukung mereka agar mau berbicara satu sama lain.

- Gunakan prosedur-prosedur persuasi.

Inilah stragi yang akan dipakai oleh seorang pekerja sosial dalam penanganan atau tahapan pada proses Resolusi konflik, dengan dasar-dasar ini lah pekerja sosial layak terlibat dalam proses resolusi konflik yang sering terjadi di Indonesia.

Selain sebagai Mediator atau Negosiator, seorang pekerja sosial mampu bisa menjadi Fasilitator dalam penyelesain konflik yang terjadi di Indonesia, dengan ,pekerja sosial sebagai Fasilitator dalam resolusi konflik maka penyelesaian konflik tersebut dapat memberikan suatu kepastian damai antara pihak-pihak yang terlibat konflik.

\section{Fasilitator}

Dalam literatur pekerjaan sosial, peranan "fasilitator" sering disebut sebagai "pemungkin" (enabler). Keduanya bahkan sering dipertukarkan satu-sama lain. Seperti dinyatakan Parsons, Jorgensen dan Hernandez (1994:188), "The traditional role of enabler in social work implies education, facilitation, and promotion of interaction and action." Selanjutnya Barker (1987) memberi definisi pemungkin atau fasilitator sebagai tanggungjawab untuk membantu klien menjadi mampu menangani tekanan situasional atau transisional. Pengertian ini didasari oleh visi pekerjaan sosial bahwa setiap perubahan terjadi pada dasarnya dikarenakan oleh adanya usaha-usaha klien sendiri, dan peranan pekerja sosial adalah memfasilitasi atau memungkinkan klien mampu melakukan perubahan yang telah ditetapkan dan disepakati bersama.

Strategi-strategi khusus untuk mencapai tujuan tersebut meliputi: pemberian harapan, pengurangan penolakan dan ambivalensi, pengakuan dan pengaturan perasaan-perasaan, pengidentifikasian dan pendorongan kekuatan-kekuatan personal dan asset-asset sosial, pemilahan masalah menjadi beberapa bagian sehingga lebih mudah dipecahkan, dan pemeliharaan sebuah fokus 
pada tujuan dan cara-cara pencapaiannya (Barker, 1987:49). Parsons, Jorgensen dan Hernandez (1994:190-203) memberikan kerangka acuan mengenai tugas-tugas yang dapat dilakukan oleh pekerja sosial:

- Mendefinisikan keanggotaan atau siapa yang akan dilibatkan dalam pelaksanaan kegiatan.

- Mendefinisikan tujuan keterlibatan.

- Mendorong komunikasi dan relasi, serta menghargai pengalaman dan perbedaan-perbedaan.

- Memfasilitasi keterikatan dan kualitas sinergi sebuah sistem: menemukan kesamaan dan perbedaan.

- Memfasilitasi pendidikan: membangun pengetahuan dan keterampilan.

- Memberikan model atau contoh dan memfasilitasi pemecahan masalah bersama: mendorong kegiatan kolektif.

- Mengidentifikasi masalah-masalah yang akan dipecahkan.

- Memfasilitasi penetapan tujuan.

- Merancang solusi-solusi alternatif.

- Mendorong pelaksanaan tugas.

- Memelihara relasi sistem.

- Memecahkan konflik.

Dalam penyelesaian konflik, sering terlihat yang menjadi Fasilitatornya bukan orang yang tepat, sehingga dengan pandangan ini, di harapkan dalam penangan kasus-kasus konflik di Indonesia seorang pekerja sosial dapat ambil bagian sebagai orang yang siap dalam resolusi konflik di Indonesia, karena pekerja sosial mempunyai kemampuan dan kerangka analisis dalam kasus penyelesaian konflik di Indonesia. Pekerja sosial, selain menjadi Mediator, negosiator, Fasilitator, pekerja sosial bisa menjadi Broker dalam penyelesaian konflik di Indonesia yang sat-saat ini sering terjadi. Peran sebagai Broker yang diperankan oleh pekerja sosial adalah sebagai berikut.

\section{Broker}

Dalam pengertian umum, seorang broker membeli dan menjual saham dan surat berharga lainnya di pasar modal. Seorang broker berusaha untuk memaksimalkan keuntungan dari transaksi tersebut sehingga klien dapat memperoleh keuntungan sebesar mungkin. Pada saat klien menyewa seorang broker, klien meyakini bahwa broker tersebut memiliki pengetahuan mengenai pasar modal, pengetahuan yang diperoleh terutama berdasarkan pengalamannya sehari-hari.Dalam konteks penanganan konflik, peran pekerja sosial sebagai broker tidak jauh berbeda dengan peran broker di pasar modal. Seperti halnya di pasar modal, dalam penanganan konflik terdapat "klien" atau "konsumen", yakni kelompok-kelompok yang bertikai. Namun demikian, pekerja sosial melakukan transaksi dalam pasar lain, yakni jaringan pertolongan sosial. Selain pengetahuan mengenai kualitas pelayanan sosial di sekitar lingkungannya, pemahaman dan penghargaan pekerja sosial terhadap nilai-nilai pluralisme (non-judgemental, individualisation, self determination), sangat penting untuk menghindari konflik kepentingan dan menjaga kenetralan. Dalam proses penanganan konflik, ada tiga prinsip utama dalam melakukan peranan sebagai broker:

- Mampu mengidentifikasi dan melokalisir sumber-sumber kemasyarakatan yang tepat.

- Mampu menghubungkan konsumen atau klien dengan sumber secara konsisten.

- Mampu mengevaluasi efektifitas sumber dalam kaitannya dengan kebutuhan-kebutuhan klien.

Disinilah seorang pekerja sosial dapat mengambil peran sebagai seorang yang mempunyai kemampuan dalam penanganan konflik, atau sebagai pihak yang siap memberikan pelayanan dalam proses penyelesaian konflik di Indonesia. 
Pekerjaan sosial memandang bahwa kedamaian sosial bukanlah keadaan yang taken for granted, sekali jadi, dan ditentukan oleh kondisi-kondisi alam. Meskipun bencana alam dapat menjadi sumber ketidakdamaian sosial, manusia merupakan faktor penentu bagi terciptanya kedamaian sosial. Ketidakdamaian sosial dapat terjadi karena struktur-struktur kekuasaan yang timpang; yang secara tidak adil menetapkan siapa yang berhak memperoleh "kedamaian" dan siapa yang tidak. Strukturstruktur tersebut dapat diidentifikasi dalam beberapa tingkatan, mulai dari tingkat global, regional, nasional dan lokal. Misalnya, kegagalan pemerintahan nasional dalam memfasilitasi terpenuhinya kebutuhan sosial dan tercapainya keadilan sosial, dapat menimbulkan pencarian kedamaian sosial melalui saluran-saluran informal dan bahkan illegal; diluar lembaga-lembaga formal negara. (edi Soeharto dlm modal kedamaian sosial \& resolusi conflik: Perspefektif pekerjaan sosial).

Perlu adanya perbaikan dari lembaga-lembaga yang sangat bertanggung jawab dalam resolusi konflik di Tanah Air Indonesia, karena saat ini Indonesia masih rentan terjadinya konflik, seperti yang kita lihat, konflik-konflik di daerah di Indonesia sering terjadi, belum satu konflik terselesaikan sudah muncul konflikk baru lagi, kalau pun sudah dai damaikan dan disuruh damai, belum beberapa bulan atau bahkan kurang dari satu bulan konflik tersebut sudah kembali meletus atau pecvah lagi. Ini mungkin sebabkan karena ketidak dewasaan bangsa Indonesia, yang masih belum mampu menerima perbedaan, dan belum mampu menerima perbedaan prinsi-prinsip dan Ideologi yang berbeda. Namun yang jelas bukan itu yang harus dibahas melainkan tingkat penyelesaian yang tepat.

\section{KESIMPULAN}

Dari beberapa uraian diatas yang penulis uraikan, maka kesempulannya bahwa yang namanya konflik tidak akan secara keseluruhan dapat di hilangkan dari kehidupan manusia, karena manusia mempunyai keinginan yang berbeda, mempunyai kepentingan yang berbeda, mempunyai tujuan yang pastinya berbeda maka sudah jelas pstinya manusia akan berbenturan dengan manusia yang lainnya ketika mereka mempunyai keinginan dan tujuan yang berbeda dari manusia yang lainnya, maka sudah tentu perbedaan ini akan menimbulkan penolakan dari pihak yang tidak setuju, sehingga akan menimbulkan suatu gesekan dan prasangka yang tidak baik antara manusia yang satu dengan yang satunya lagi.

Namun ini tentu bukan harus menjadi hambatan dalam proses mewujudkan kedamaian sosial dalam tataran kehidupan manusia di dunia. Memang selama ada manusia di bumi ini, maka keteraturan sosial dan tatan nilai-nilai dan norma-norma dalam kehidupan akan mengalami gangguan, namun bukan itu yang jadi pilihan, melainkan bagai mana caranya kita menaggapi dan menyikapi perbedaan, terutama konflik-konflik yang terjadi di Indonesia. Melaikan bagaimana menyelesaikankannya, dan bagai mana proses penyelesaiannya sehingga mempunyai kesepakatan yang fositif dalam setiap penyelesaian konflik

Dalam prosesnya, penyelesaian konflik:

- -Harus sesuai dengan Hukum dan UU Negara republik Indonesia yang telah di sepakati bersama oleh seluruh Masyarakat melalui pemerintah dan legislatifnya.

- -Dalam penyelesaian dan penyidikan yang dilakukan oleh aparat penegak hukum harus sesuai dengan peraturan penyidikan atau uu

- Memberikan keputusan atau hukuman kepada mereka yang membuat konflik haruslah sesuai dengan uu, dan tindakan yang tegas terhadap mereka yang terbukti bersalah

- -Dalam proses penyelesaian konflik secara Litigasi dan Non-Litigasi harus melibatkan Mediator,Negosiator, fasilitator dan harus orang yang tepat dan memahami proses itu. Seperti pekerja sosial yang mestinya dilibatkan dalam prosesnya.

\section{DAFTAR PUSTAKA}

Sumber Buku : 
Frans Parera dan Thomas Santoso (eds), Indonesia di Persimpangan Kekuasaan: Dominasi Kekerasan atas Dialog Publik, Jakarta: The Go-East Institute, hal.1-7.

Jim Ife. 2006 Community Development . Yogyakarta : Pustaka Belajar.

Kleden dan John Julaman (eds), Timur dan Barat di Indonesia: Perspektif Integrasi Baru. Jakarta:

The Go-East Institute, (hal.117-128)

Kleden, Ignas (2000), Epistemologi Kekerasan di Indonesia, dalam Paul Tahalele,

Salusu. Jonatan (2000). Stabilitas Nasional, Perdamaian dan Komunikasi Politik. dalam Ignas

Wibawa, Budhi dkk. 2010. Dasar-Dasar Pekerjaan Sosial. Bandung: Widya Padjadjaran

\section{Sumber artikel, jurnal dan hasil penelitian :}

www.policy.hu/suharto/modul_a/makindo_20.htm(21-12-2014 : 14.00)

http://devisofiah23.blogspot.jp/2013/09/contoh-artikel-tentang-konflik-sosial.html (21-12-2014 : 14.33)

ratnandoet.wordpress.com/konflik-sosial/(21-12-2014 : 15.23) 